\title{
Mosses as indicators of atmospheric metal deposition in an industrial area of southern Brazil
}

\author{
Aline Correa Mazzoni ${ }^{1,3}$, Rosane Lanzer ${ }^{1}$, Juçara Bordin ${ }^{2}$, Alois Schäfer ${ }^{1}$ and Ronaldo Wasum ${ }^{1}$
}

Recebido em 29/09/2011. Aceito em 25/04/2012

\begin{abstract}
RESUMO
(Musgos como indicadores da deposição atmosférica de metais em uma área industrial do sul do Brasil) Caxias do Sul sedia o segundo maior pólo metal mecânico do Brasil, apresentando elevado risco de contaminação atmosférica. Com o objetivo de identificar espécies úteis como indicadoras da deposição atmosférica de metais, foram analisadas 15 espécies de musgos procedentes da zona urbana e da área rural e espécimens depositados no Herbário da Universidade de Caxias do Sul. Os metais $(\mathrm{Zn}, \mathrm{Ni}, \mathrm{Cd}, \mathrm{Cr}, \mathrm{Cu}$ e $\mathrm{Pb}$ ) foram determinados por meio de Espectrometria de Absorção Atômica (AAS). O Teste de Mann-Whitney indicou diferenças significativas nas concentrações de $\mathrm{Zn}, \mathrm{Cu}, \mathrm{Pb}$ e $\mathrm{Cr}$ entre as áreas urbana e rural. Um aumento significativo na presença de $\mathrm{Zn}, \mathrm{Cd}, \mathrm{Cu}$ e $\mathrm{Pb}$ foi evidenciado nas amostras recentes. As espécies Thuidium tomentosum Besch., Sematophyllum subpinnatum (Brid.) E. Britton, Helicodontium capillare (Hedw.) A. Jaeger, Schlotheimia jamesonii (W.-Arnott) Brid. e Meteorium deppei (Hornsch. ex Müll. Hal.) Mitt. são indicadas como potenciais biomonitores da deposição atmosférica de metais.
\end{abstract}

Palavras-chave: bioindicadores, Bryophyta, metais pesados, poluição atmosférica, Rio Grande do Sul

\begin{abstract}
(Mosses as indicators of atmospheric metal deposition in an industrial area of southern Brazil). Caxias do Sul hosts the second largest metal-mechanic pole in Brazil, which increases the risk of atmospheric contamination. With the aim of identifying species that might be useful as indicators of atmospheric deposition of metals, 15 species of mosses from an urban and a rural setting were analyzed and compared with specimens deposited at the Herbarium of the Universidade de Caxias do Sul. Metal concentrations ( $\mathrm{Zn}, \mathrm{Ni}, \mathrm{Cd}, \mathrm{Cr}, \mathrm{Cu}$ and $\mathrm{Pb}$ ) were determined using Atomic Absorption Spectrometry (AAS). The Mann-Whitney test indicated concentrations of $\mathrm{Zn}, \mathrm{Cu}, \mathrm{Pb}$ and $\mathrm{Cr}$ that were significantly different between the urban and rural areas. Additionally, Concentrations of $\mathrm{Zn}, \mathrm{Cd}, \mathrm{Cu}$ and $\mathrm{Pb}$ were significantly higher in recently collected samples. The species Thuidium tomentosum Besch., Sematophyllum subpinnatum (Brid.) E. Britton, Helicodontium capillare (Hedw.) A. Jaeger, Schlotheimia jamesonii (W.-Arnott) Brid. and Meteorium deppei (Hornsch. ex Müll. Hal.) Mitt. are potential biomonitors of atmospheric metal deposition.
\end{abstract}

Key words: atmospheric pollution, bioindicators, Bryophyta, heavy metals, Rio Grande do Sul

\section{Introduction}

Organisms in vivo are often used as active or passive bioindicators of environmental stress (Markert et al. 2003). Certain plant species in particular have been useful in determining the degree of atmospheric pollution, and have been used as biomonitors of specific contaminants such as ozone (Vergé 2002), fluoride (Oliva \& Figueiredo 2005), fossil fuel byproducts (Klumpp et al. 2001), and trace metals (Husk et al. 2004).
Bryophytes in the broad sense, are cryptogamous, non-vascular, and generally small plants found in almost every environment, particularly where humidity is high. They play an important role in soil formation and plant succession. With 17,800 described species, bryophytes are the second largest group of terrestrial plants (Gradstein et al. 2001). They are currently divided into three distinct groups: Bryophyta (mosses), Marchantiophyta (hepatics or liverworts) and Anthocerotophyta (hornworts) (Buck \& Goffinet 2000). Of these, mosses are the largest, with ca.

\footnotetext{
${ }^{1}$ Universidade de Caxias do Sul, Centro de Ciências Agrárias e Biológicas, Caxias do Sul, RS, Brazil

${ }^{2}$ Universidade Estadual do Rio Grande do Sul, Litoral Norte-Osório, RS, Brazil

${ }_{3}^{3}$ Author for correspondence: alinecmazzoni@gmail.com
} 
12,000 species, encompassing the broadest morphological variation (Vanderpoorten \& Goffinet 2009).

Despite certain limitations stemming from abiotic (e.g., precipitation, elevation above the sea level) and biotic factors (moss species, age of moss, growth rate of a species), the use of mosses is still one of the best methods available to estimate the trace element burden in the environment (Grodzinska \& Szarek-Lukaszewska 2001). Mosses are particularly useful in evaluating environmental conditions that are being constantly modified by humans for several reasons. For instance, mosses lack a cuticle and a vascular system, which causes them to accumulate metals passively, acting as ion exchangers (Grodzinska 1999; Onianwa 2000). Also, they are broadly distributed, and occur in both clean and industrial areas (Grodzínska \& Szarek-Lukaszewska 2001; Korzekwa et al. 2007; Pedroso 2007).

The use of mosses as indicators of atmospheric pollution by heavy metals was developed in Sweden (Rühling \& Tyler 1973) and is now well established in many European countries (Galsomies et al. 1999; Siewers et al. 2000; Grodzinska \& Szarek-Lukaszewska 2001; Reimann et al. 2001; Pesch \& Schroeder 2006). Mosses are used to determine the present extent of environmental pollution in vast as well as in small areas (Zechmeister 1997; Galsomies et al. 1999; Grodzinska et al. 1999; Steinnes et al. 2008), and to help estimate the environmental concentrations and effects of contaminants (Siewers et al. 2000; Steinnes et al. 2005, Pesch \& Schroeder 2006). Every five years, since 1990, at least 21 European states have conducted projects aimed to detect spatial and temporal trends of metal accumulation in terrestrial ecosystems (Pesch \& Schroeder 2006).

A total of 885 moss taxa are known to occur in Brazil (Costa et al. 2010), of which 536 have been recorded from Rio Grande do Sul (Bordin \& Yano 2010). Despite their diversity in the country, mosses have rarely been used in air quality biomonitoring (Carneiro 2004). One exception is Sphagnum, which has been used to monitor environmental pollution levels (Gutberlet 1996; Carneiro 2004; Henriques 2007).
Caxias do Sul, the second largest city in the state of Rio Grande do Sul, is one of the largest metal mechanic industry centers in Brazil. Because it harbors several metallurgical and galvanic industries, the atmosphere of Caxias do Sul is contaminated with trace metals (SIMECS 2002) that interfere with the ecosystem and impact human health.

Our study is an attempt to identify potential moss species that can be used as biomonitors of atmospheric deposition of metals in Brazil. It is important for two reasons: first, results can be used to demonstrate the increased metal air pollution in this urban-industrial center; second, species that are identified as potentially useful in air quality control can be prioritized in further studies, because taxonomic difficulties, lack of surveys and little knowledge about the biology, physiology and geographical distribution of most moss species have hampered their use as indicators of air quality in the country.

\section{Materials and methods}

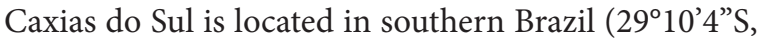
$51^{\circ} 10^{\prime} 44^{\prime \prime} \mathrm{W}$ ), at altitudes ranging from $740 \mathrm{~m}$ to $820 \mathrm{~m}$. It has an estimated population of 410,166 inhabitants (IBGE, 2009). The climate is Cfb (Kottek et al. 2006), with average annual temperature of $15.9^{\circ} \mathrm{C}$ and a well-distributed annual precipitation of $1,821 \mathrm{~mm} /$ year.

We selected four sampling sites in an urban environment, where automobile traffic and factories are a strong influence, and four sites in a rural area, located $45 \mathrm{~km}$ from the urban center, where agriculture is the main economic activity (Fig. 1).

Out of the 91 species of mosses cited by Bordin \& Yano (2009) for Caxias do Sul, we selected 15 for analysis: Meteorium deppei (Hornsch. ex Müll. Hal.) Mitt., Macromitrium guatemaliense Müll. Hal., Orthostichella rigida (Müll. Hal.) B.H. Allen \& Magill, Vesicularia vesicularis (Schwägr.) Bro-
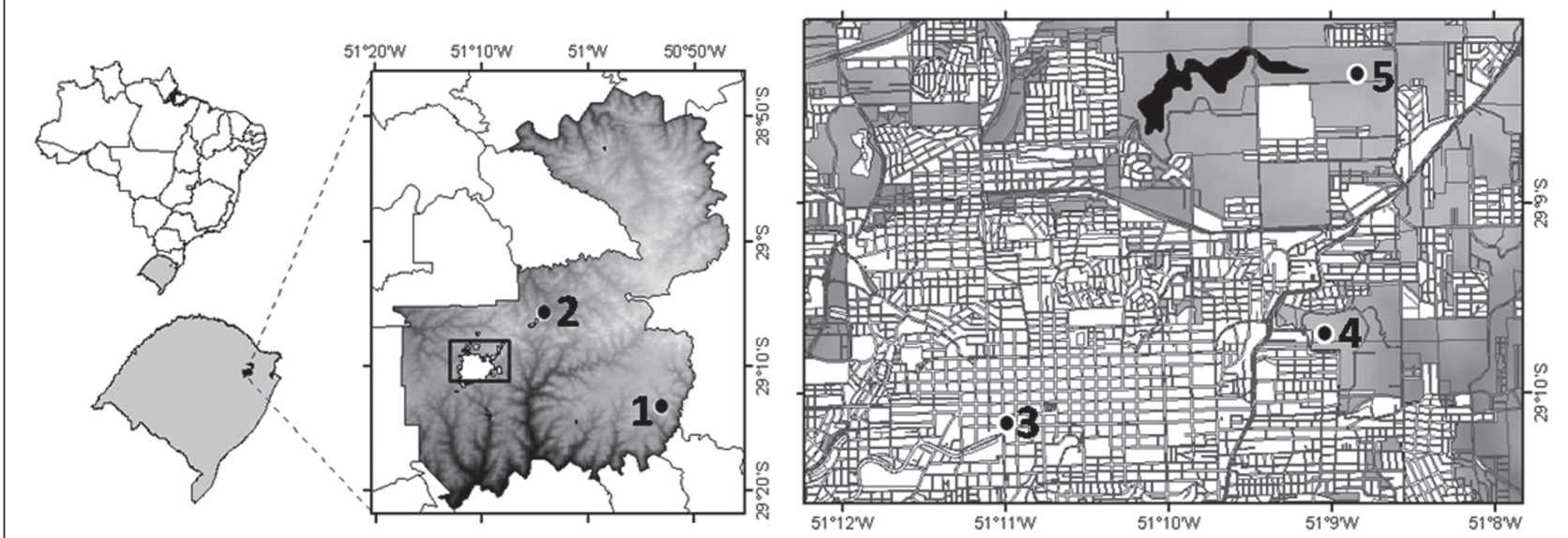

Figura 1. Sampling points in the city of Caxias do Sul. (1). Rural area: District de Vila Oliva; (2-5). urban area: (2). Neighborhood of Ana Rech, (3). City center, (4). University of Caxias do Sul, (5). Botanical Garden of Caxias do Sul. 
th., Sematophyllum subpinatum (Brid.) E. Britton, Helicodontium capillare (Hedw.) A. Jaeger, Schloteimia jamesonii (W.-Arnott) Brid., Thuidium tomentosum Besch., Squamidium nigricans (Hook.) Broth., Pilotrichella flexilis (Hedw.) Ångstr., Phyllogonium viride Brid., Prionodon densus (Hedw.) Müll. Hal., Zelometerium ambiguum (Hornsch. in Mart.) Manuel, Leucobryum crispum Müll. Hal. and Pyrrhobryum spiniforme (Hedw.) Mitt. Among these, only O. rigida and $T$. tomentosum occur both in urban and rural settings.

We collected samples in 2003 and 2004 (during fall and winter). Mosses were collected from the stems of trees, identified and stored according to a technique commonly used for the group (Yano 1984). Vouchers were deposited in the Herbarium of the University of Caxias do Sul (HUCS). Some duplicate vouchers were deposited in the Herbarium of the State "Maria P. Eneyda Kauffmann Fidalgo (SP) "in São Paulo.

We examined nine samples from the urban area and nine samples from the rural area, totaling eight and nine species, respectively. In order to ascertain the atmospheric deposition of metals in specimens from the HUCS, we analyzed nine samples collected between 1947 and 1992. Of this total, six samples including four species came from the urban area and three species were collected in the rural area.

Dry and macerated samples were sent to the Center for Environmental Research, University of Saarland (Germany) for analysis. The material was ground, cold-dried, pressurized and liquefied by digestion with $\mathrm{HNO}_{3}$. A subsample $(150 \mathrm{~g})$ was weighed and heated under pressure at $17^{\circ} \mathrm{C}$ for 10 hours. Lead $(\mathrm{Pb})$, Cadmium $(\mathrm{Cd})$, Chromium $(\mathrm{Cr})$, Copper $(\mathrm{Cu})$, Nickel $(\mathrm{Ni})$ and zinc $(\mathrm{Zn})$ were detected and quantified by flame atomic absorption spectroscopy (FAAS), using an AAS Perkin \& Elmer PE 3000. The concentration of metals was expressed in $\mu \mathrm{g} \cdot \mathrm{g}^{-1}$ dry weight.

The comparison between the samples was carried out considering the metal concentration in all species. Percentile calculations were used to ascertain metal accumulation in mosses. The values above $90 \%$ in the percentile calculation were considered high.

The differences in metal deposition were evaluated by the Mann-Whitney test $(\mathrm{p}=0.05)$. Normality was ascertained using the Kolmogorov-Smirnov test $(\mathrm{p}=0.05)$. Statistical analyses did not include herbarium species from the rural area, due to the small number of samples.

\section{Results and discussion}

\section{Trace metal concentrations in naturally-occurring moss}

The results pertaining to metal concentrations in species are summarized in Tables 1 and 2.

Mosses from the urban area had about two times more $\mathrm{Ni}, \mathrm{Cd}, \mathrm{Pb}$ and $\mathrm{Cr}$, and almost six times more $\mathrm{Zn}$ (Tables 1 and 2) than samples from the rural area. Studies conducted by the authors in Caxias do Sul analyzing metal deposition in Lolium multiflorum (unpublished data) showed that the concentration of $\mathrm{Zn}$ are classified as critical in the urban area. According to Onianwa (2001), the highest concentration of metals in naturally-occurring moss is usually found in the vicinities of pollution sources, gradually decreasing as the distance from the source increases.

The metallurgical and galvanic industries in Caxias do Sul employ materials such as cadmium, copper, nickel, tin, gold, silver, chromium and zinc. Galvanization with iron is the main source of $\mathrm{Zn}$ emission (Duarte \& Pasqual 2000)

When urban and rural areas were compared with regard to metal accumulation in moss, a significant difference was verified in the concentration of $\mathrm{Zn}, \mathrm{Cu}, \mathrm{Pb}$ and $\mathrm{Cr}$ (Fig. 2). The sources of these metals in the urban area are vehicular traffic and industries (Grodzinska et al. 2001; Pesch \& Schroeder 2006).

Table 1. Metal concentration in mosses ( $\left.\mu \mathrm{g} \cdot \mathrm{mg}^{-1}\right)$ in the urban area of Caxias do Sul (2003-2004)

\begin{tabular}{|c|c|c|c|c|c|c|}
\hline & \multicolumn{6}{|c|}{ Urban area } \\
\hline & $\mathrm{Zn}$ & $\mathrm{Cd}$ & $\mathrm{Ni}$ & $\mathrm{Cu}$ & $\mathrm{Pb}$ & $\mathrm{Cr}$ \\
\hline Mean & 142,2011 & 0,337778 & 23,18889 & 45,92778 & 29,17111 & 24,03889 \\
\hline Median & 180 & 0,297 & 7 & 36,8 & 20,73 & 9,5 \\
\hline Maximum & 250 & 0,563 & 93 & 86 & 77 & 66 \\
\hline Minimum & 24,73 & 0,1 & 0,69 & 18 & 7,54 & 5,14 \\
\hline
\end{tabular}

Table 2. Metal concentration in mosses ( $\mu$ g.mg ${ }^{-1}$ ) in the rural area of Caxias do Sul (2003-2004)

\begin{tabular}{lcccccc}
\hline & \multicolumn{3}{c}{ Rural area } & & & \\
\cline { 2 - 7 } & Zn & $\mathrm{Cd}$ & $\mathrm{Ni}$ & $\mathrm{Cu}$ & $\mathrm{Pb}$ & $\mathrm{Cr}$ \\
Mean & 34,2577 & 0,2706 & 5,8922 & 18,8522 & 9,1777 & 3,7966 \\
Median & 30,67 & 0,2275 & 2,91 & 16,83 & 9,65 & 3,77 \\
Maximum & 50,57 & 0,542 & 21,07 & 35,15 & 15,79 & 7,78 \\
Minimum & 19,74 & 0,05 & 0,2 & 12,95 & 4,86 & 1,48 \\
\hline
\end{tabular}




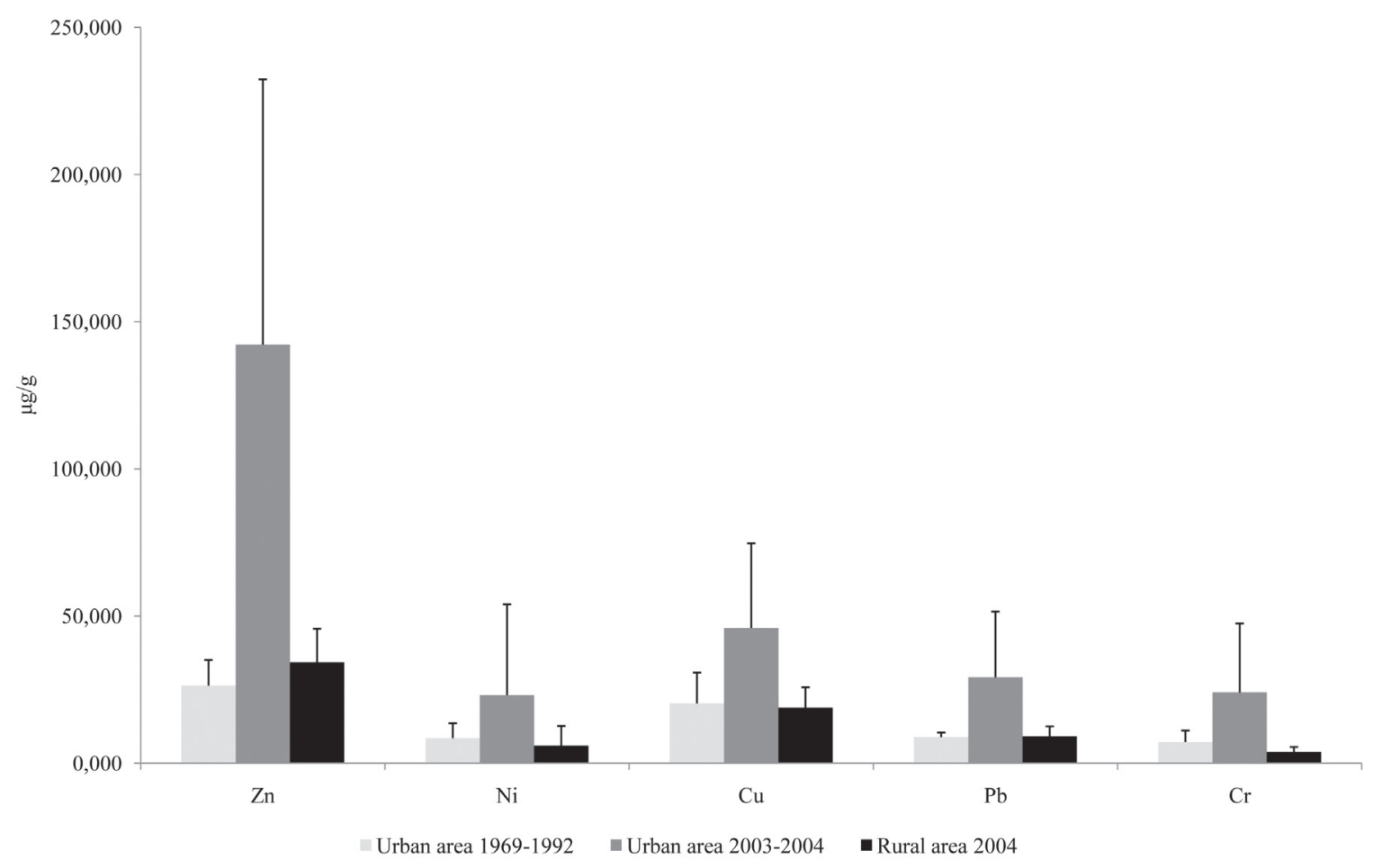

Figura 2. Comparison between the concentrations of six trace metals determined in naturally occurring mosses collected in urban and rural areas and in herbarium mosses.

The concentrations of Cd and Ni were high in both areas. The presence of these metals in rural areas may result from the use of phosphate fertilizers (Gonçalves Jr. et al 2000).

Of the species surveyed, S. subpinnatum, H. capillaris, T. tomentosum, S. jamesonii and M. deppei, had the highest concentrations of $\mathrm{Zn}$. The first three species were heavily contaminated with virtually every metal surveyed.

The five species mentioned above belong to the class Bryopsida, also known as ectohydric mosses. They are considered good indicators of environmental quality because they obtain almost all their water and nutrients directly from the air, through their thin leaves. This is because their water conductive tissues are either poorly developed or completely lacking. Species that have well-developed internal conductive vessels are not good atmospheric indicators (Goffinett \& Shaw 2008).

Many bryophytes have developed adaptive strategies to accumulate water and survive in inhospitable places. For instance, Hylocomium splendens (Hedw.) B.S.G. and Thuidium tamariscinum (Hedw.) Bryol. Ieur. have paraphyllia. The latter has been used in France (Galsomiès et al. 1999) to biomonitor atmospheric deposition. Paraphyllia (leaflike appendages between the leaves) create capillary spaces much like a tomentum that decreases water loss and possibly the loss of other substances (Glime 2006). Water retention is also accomplished by papillae, which form interstitial spaces between them that function as capillary system drivers (Proctor 1984). Thuidium tomentosum and M. deppei have paraphyllia and papillae, which may facilitate the accumu- lation of metals, thus explaining the high concentrations of metals (especially $\mathrm{Zn}$ ) found in samples of these species from the urban area near metal-mechanical facilities (Fig. 2).

Thuidium tomentosum, present in all regions of Brazil (Bordin \& Yano 2009; 2010), was the only species found in both urban and in rural areas. The wide geographical distribution of this species, associated with its peculiar biological characteristics, makes it a good candidate for biomonitoring. Another species of the same genus, $T$. gratum (P. Beauv.) Jacq. showed levels of $\mathrm{Pb}$ up to 250 ppm near busy roadsides in Nigeria (Onianwa 2000). Sematophyllum subpinnatum, $H$. capillaris, $S$. jamesonii and M. deppei, found in almost all Brazilian regions (Bordin \& Yano 2010), are also potential biomonitors of atmospheric metal deposition.

\section{Trace metal concentrations in herbarium moss}

Metallurgical and chemical industries emerged in Caxias do Sul by 1913, and grew significantly from 1920 on (Lazzaroto 1981). Most of the industrial expansion, however, took place after 1960. The rate of urban population growth in the region between 1960 and 1996 was approximately 300\% (Breitbach, 2002). According to data from IBGE (2009), the population of Caxias do Sul increased 29\% over the past 18 years.

Herbarium moss samples have been demonstrated as a useful resource to ascertain past levels of environmental contamination (Herpin et al. 1997). The herbarium samples of Orthostichopsis tenuis (A. Jaeger) Broth., Pterobryon 
densum (Schwägr.) Hornsch, P. flexilis and P. densus, used in this contribution, were collected between 1969 and 1992 from an urban area, and those of Syrrhopodon gaudichaudii Mont., O. tenuis and P. viride were collected 1947, in a rural setting.

When compared with herbarium samples obtained from the urban area, the recently collected moss samples showed a significant increase $(\mathrm{p}<0.05)$ in concentrations of $\mathrm{Zn}$, $\mathrm{Cd}, \mathrm{Cu}$ and $\mathrm{Pb}$ (Fig. 2). Among the non-essential and toxic elements, $\mathrm{Pb}$ is strongly associated with urban growth (Galsomies et al 1999). However, the most significant increase was observed in the concentration of $\mathrm{Zn}$, six times higher than in herbarium samples.

Contrary to what has been observed in this study, the air quality in most European cities, ascertained through moss monitoring in 1990, 1995 and 2000 (Siewers et al., 2000, Grodzinski \& Szarek-Lukaszewska, 2001, Pesch \& Schroeder, 2006), has significantly improved as a result of emissions control.

The four herbarium species (O. tenuis, P. flexilis, $P$. densus and $P$. densum) we surveyed are not among the species sampled recently, and were not reported by Bordin \& Yano (2009) for urban centers. Pilotrichella flexilis and P. densus were collected in 2003 and 2004 in rural areas. These species usually grow in forests (Buck 1988) and are likely to be sensitive to urban pollution. This is however a hypothesis and needs to be tested.

None of the trace metals were found in high concentrations in herbarium mosses collected in the urban setting. Furthermore, Cd was not detected in herbarium mosses from the latter. One urban sample from the herbarium had a high concentration of $\mathrm{Ni}$, probably a result of pesticide use.

\section{Biomonitors of atmospheric deposition of heavy metals}

Urbanization and growth of the metallurgical industry are directly correlated with increased air pollution by metals in the urban center. This hypothesis is corroborated by the statistically significant similarity between the values found in mosses from urban and rural settings in 2003 and 2004 (Fig. 2).

Emission control measurements require long-term sampling in a large number of sampling sites (Wolterbeek 2002). They also require the selection of species that occur in both settings and whose biology and ecology are well-known.

The main species used to survey atmospheric deposition of metals in Europe, Pleurozium schreberi (Willdenow ex Bridel) Mitten and Hylocomium splendens, are well studied (Ceburnis 1997; Berg \& Steinnes 1997; Siewers \& Herpin 1998; Grodzinska 1999; Taminnen 2004), having well-defined growth rates and reproductive cycles (Longton \& Greene 2005).

The potential for the use of mosses in the assessment of air quality in Brazil is promising, given their richness in species. The fact that $P$. flexilis and $P$. densus are absent in current urban samples, but present in rural areas, indicates that the environmental integrity of the latter has been preserved. We suggest that S. subpinnatum, H. capillaris,
T. tomentosum, S. jamesonii and M. deppei are good candidates for biomonitoring atmospheric deposition of metals due to their ability to accumulate different metals, and the fact that they are widely distributed.

\section{Conclusions}

The following species have a potential as bioindicators: S. subpinnatum, H. capillaris, T. tomentosum, S. jamesonii, M. deppei, P.flexilis and P. densus. However, there is a need to broaden our knowledge of the geographic distribution, biology, ecology and ecophysiology of theses species, in order to better understand the processes of accumulation and transport of substances important to air pollution control.

\section{Aknowledgements}

We thank Dr. Olga Yano for the identification of part of the samples; Dr. Jochen Kubiniok for performing the analysis of metals in the mosses; BSc Cassiano Alves Marchett for making the maps; and Dr. Denilson Fernandes Peralta for the critical review of an earlier draft of this manuscript.

\section{References}

Berg, T. \& Steinnes, E. 1997. Use of mosses (Hylocomium splendens and Pleurozium schreberi) as biomonitors of heavy Metal deposition: from relative to absolute Deposition values. Environmental Pollution 98(1): 61-71.

Bordin, J. \& Yano, O. 2009. Briófitas do centro urbano de Caxias do Sul, Rio Grande do Sul, Brasil. Hoehnea 36 (1): 7-71.

Bordin, J. \& Yano, O. 2010. Lista das briófitas (Antocerathophyta, Bryophyta, Marchantyophyta) do Rio Grande do Sul, Brasil. Pesquisas 61: 39-170.

Breitbach, Áurea C.M. 2001. O desenvolvimento da região de Caxias do Sul. Anais do XXI Encontro Estadual de Geografia, Caxias do Sul.

Buck, W.R. 1998. Pleurocarpous Mosses of the West Indies. Memoirs of The New York Botanical Garden 82: 1-400.

Buck, W.R. \& Goffinet, B. 2000. Morphology and classification of mosses. Pp 71-123. In: Shaw, A. J. \& Goffinet, B. (Eds.). Bryophyte Biology. Cambridge, Cambridge University Press.

Costa, D.P.; Camara, P.E.A.S.; Porto, K.C.; Luizi-Ponzo, A.P \& Ilkiu-Borges, A.L. 2010. Musgos. In: Catálogo de Plantas e Fungos do Brasil. v. 1. Rio de Janeiro, Andrea Jakobsson Estúdio, Instituto de Pesquisas Jardim Botânico do Rio de Janeiro.

Carneiro, R.M.A. 2004. Bioindicadores vegetais de poluição atmosférica: uma contribuição para a saúde da comunidade. Dissertação de Mestrado em Enfermagem e Saúde Pública. Universidade de São Paulo, Ribeirão Preto.

Ceburnis, D.; Rühling, A \& Kivetkus, K. 1997. Extended study of atmospheric heavy metal deposition in Lithuania based on moss analysis. Environmental monitoring and assessment 47: 135-152.

Duarte, R.P.S. \& Pasqual, A. 2000. Avaliação do Cádmio (Cd), Chumbo $(\mathrm{Pb})$, Níquel $(\mathrm{Ni})$ e Zinco $(\mathrm{Zn})$ em solos, plantas e cabelos humanos. Energia na Agricultura 15(1): 46-57

Galsomies, L.; Letrouit. M.A; Deschamps, C.; Savanne, D. \& Avnaim, M. 1999. Atmospheric metal deposition in France: initial results on moss calibration from the 1996 biomonitoring. The Science of the Total Environment 232: 39-47

Glime, J. 2006. Bryophyte Ecology. Published online at http://www. bryoecol.mtu.edu/. (Acesso em 09/07/2010) 
Goffinet, B. \& Shaw, J. 2008. Bryophyte Biology. 2 ed. Cambridge, Cambridge University Press.

Gonçalves Jr., A.C.; Luchese, E.B.; Lenzi, E. 2000. Avaliação da fitodisponibilidade de Cádmio, Chumbo e Crômio, em soja cultivada em latossolo vermelho escuro tratado com fertilizantes comerciais. Quimica Nova 23(2): 173-177.

Gradstein, S.R.; Churchill, S.P. \& Salazar-Allen, N. 2001. Guide to the Bryophytes of Tropical America. Memoirs of The New York Botanical Garden 86: 1-577.

Grodzińska, K.; Szarek-Łukaszewska, G.; Godzik, B. 1999. Survey of heavy metal deposition in Poland using mosses as indicators. The Science of the Total Environment 229(1): 41-51.

Grodzińska K., Szarek-Łukaszewska G. 2001 .Response of mosses to heavy metal deposition in Poland - na overview. Environmental Pollution 114(3): 443-451.

Gutberlet, J. 1996. Impactos ambientais em conseqüência das emissões industriais. Pp. 115-200. In: Cubatão: Desenvolvimento, exclusão social, degradação ambiental. São Paulo, Edusp.

Henriques, A.R.; Sanches, P.; Madail, R.H; Larre, C.F.; Mendes, C.R.; Lima, M.G.S. \& Dode, J. 2007. Detecção de Cádmio no Ar Atmosférico Através do Biomonitoramento Ativo da Poluição com Sphagnum sp. In:XVI Congresso de Iniciação Científica e IX Encontro de Pós-Graduação, Pelotas.

Herpin, U.; Markert, B.; Weckert, V.; Berlekamp, J.; Friesed, K.; Siexers, U.E. \& Lieth, H. 1997. Retrospective analysis of hevy metal concentrations at selected locations in the Federal Republican of Germany using moss material from a herbarium. The Science of the Total Environment 205: 1-12

Husk, G.J.; Weishampel, J.F. \& Schlesinger, W.H. 2004. Mineral dynamics in Spanish moss, Tillandsia usneoides L. (Bromeliaceae), from central Florida, USA. The Science of the Total Environment 165-172.

IBGE (Instituto Brasileiro de Geografia e Estatística). 2009. Cidades. Disponível em http://www.ibge.gov.br, (Acesso em 30/10/2009).

Kottek, M.J.; Grieser, J.; Beck, C.; Rudolf, B. \& Rubel, F. 2003. World map of the Köppen-Geiger climate classification updated. Meteorol 15: 259-263.

Lazzarotto, V. 1981. Pobres Construtores de Riqueza. Caxias do Sul, EDUCS.

Longton, R.E. \& Greene, S.W. 2005. The Growth and Reproductive Cycle of Pleurozium schreberi (Brid.) Mitt. Annals of Botany 33(1): 83-105.

Oliva, M.A. \& Figueiredo, J.G. 2005. Gramíneas bioindicadoras da presença de flúor em regiões tropicais. Revista Brasileira de Botânica 28(2):389-397.
Onianwa, P.C. 2001. Monitoring atmospheric metal pollutions: a review of the use of mosses as indicators. Environmental Monitoring and Assessment 71(1): 13-50

Pesch, R. \& Schroeder, W. 2006. Mosses as bioindicators for metal accumulation: statistical aggregation of measurement data to exposure indices. Ecological Indicators 6(1): 137-152.

Pedroso, A.N.V. 2007. Poluentes Atmosféricos \& Plantas Bioindicadoras. In: Curso de Capacitação de Monitores e Educadores. Programa de Pós-graduação em Biodiversidade Vegetal e Meio Ambiente, Instituto de Botânica da Secretaria do Meio Ambiente.

Reimann, C.; Niskavaara, H.; Kashulina, G.; Filzmoser, P.; Boyd, R.; Volden, T.; Tomilina, O. \& Bogatyrev, I. 2001. Critical remarks on the use of terrestrial moss (Hylocomium splendens and Pleurozium schreberi) for monitoring of airborne pollution. Environmental pollution 113(1): 41-57.

Rühlinger, A \& Tyler, G. 1973. Heavy metal deposition in Scandinavian. Water, Air and Soil Pollution 2(4): 445-455.

Siewers, U.; Herpin, U. \& Strassburg, S. 2000. Schwermetalleinträge in Deutschland, Moos-Monitoring 1995/96 Teil 2. Geologisches Jahrbuch. v. 3. Hannover.

SIMECS - Sindicato das Indústrias Metalúrgicas, Mecânicas e de Material Elétrico de Caxias do Sul - http://www.simecs.com.br, 2002.

Steinnes, E.; Frontasyeva, M. V.; Gundorina, S. F. \& Pankratova, Yu. S. 2008. Identification of metal emissions from adjacent point sources in Northern Norway usin moss biomonitoring and factor analysis. Chem. Anal. (Warsaw) 53(6): 877-886.

Tammine, P.; Starr M. \& Kubin, E. 2004. Element concentrations in boreal, coniferous forest humus layers in relation to moss chemistry and soil factors. Plant and Soil 259(1-2): 51-58.

Vanderpoorten, A. \& Goffinet, B. 2009. Introduction of Bryophytes. Cambridge, Cambridge University Press.

Vergé, X.; Chapuis, A. \& Delpoux, M. 2002. Bioindicator reliability: the example of Bel W3 tobacco (Nicotiana tabacum L.). Environmental Pollution 118(3): 337-349.

Wolterbeek, B. 2002. Biomonitoring of trace element air pollution: principles, possibilities and perspectives. Environmental Pollution 120(1): 11-21.

Yano, O. 1984. Briófitas. In: Fidalgo, O. \& Bononi, V.L.R. (Coord.) Técnicas de coleta, preservação e herborização de material botânico. São Paulo, Instituto de Botânica.

Zechmeister, H. 1997. Heavy Metal Deposition in Austria. (Schwermetalldepositionen in Österreich) Wien - Monographien, Band 94. 